\title{
Assessment of Adverse Events Reported to The Poison Control and Forensic Chemistry Center in Jeddah, Saudi Arabia
}

\author{
Nawaf Almuntashiri ${ }^{1,2}$, Osama Alsahafi ${ }^{1,3}$, Mohammad Gamaruddin ${ }^{1,4}$, \\ Sherif Attia Hammad ${ }^{5}$, Mansour Tobaiqy ${ }^{6}$
}

${ }^{1}$ College of Applied Medical Sciences, University of Jeddah, Jeddah, Saudi Arabia

${ }^{2}$ Pharmaceutical Supply Chain Management, Medical Supply, Makkah Health Affairs, Ministry

of Health, Saudi Arabia

${ }^{3}$ Pharmacy Department, Khulais General Hospital, Makkah Health Affairs, Ministry of Health, Saudi Arabia

${ }^{4}$ Pharmacy Department, Alharam Emergency Hospital, Makkah Health Affairs, Ministry of Health, Saudi Arabia

${ }^{5}$ Jeddah Poison Control Center, Makkah Health Affairs, Ministry of Health, Saudi Arabia

${ }^{6}$ Department of Pharmacology, College of Medicine, University of Jeddah, Jeddah, Saudi Arabia

\author{
Corresponding Author \\ Dr. Mansour Tobaiqy \\ BSc, MSc, Clin Pharmacol, PhD, PgCert \\ Assistant Professor \\ Department of Pharmacology \\ College of Medicine \\ University of Jeddah \\ Visiting Professor, Robert Gordon University, UK \\ P. O. Box 45311 Jeddah 21512 \\ E-mail: mtobaiqy@uj.edu.sa
}




\begin{abstract}
Background: Poisoning is a major public health threat in many countries across the globe, including Saudi Arabia. Poison control facilities help to provide immediate treatment to the patients affected by poisoning. Poisoning cases from various regions of the Kingdom are reported to the Poison Control and Forensic Chemistry Centers.

Aims: This study aimed at assessment of the demographics, risk factors and management of various poisoning cases reported at the Poison Control and Forensic Chemistry Center in Jeddah, Saudi Arabia.

Methods: Data was collected from the poisoning archived forms, between 01-01-2019 to 30-122019. A data collection sheet was designed to collect information about the region of call, age and gender of the patient, type, place, route and pattern of poisoning. All the data was analyzed through SPSS software.

Results: Most cases of intoxications were occurred and reported from the Western Region of Saudi Arabia $(n=97,38 \%)$, and were for males $(n=137,54 \%)$. The majority of poisoning cases occurred in children under 5-years of age $(\mathrm{n}=198,78 \%)$. Poisoning cases were accidental $(\mathrm{n}=233,92 \%)$ and intentional $(\mathrm{n}=11,4 \%)$, and most $(\mathrm{n}=246,96 \%)$ occurred at home. Drug poisoning was more common $(n=155,61 \%)$ than chemical poisoning $(n=92,36 \%)$. The rout of poisoning was oral in the vast majority of incidents $(n=242,94 \%)$. Intentional poisoning was more common in females $(n=8,3 \%)$. All poisoning reports initiated by physicians and other healthcare professionals $(n=253,100 \%)$, within one hour of the poisoning $(n=144,57 \%)$ and after one home $(n=109,43 \%)$. Decontamination with active charcoal $(n=62,24 \%)$ was the most common method recommended to manage intoxicated patients, followed by gastric lavage $(\mathrm{n}=9$, $3.5 \%)$.
\end{abstract}

Conclusion: The current study assessed the reports of adverse events in a poisoning center in Saudi Arabia, most cases were related to medicines, followed by chemicals and most occurred at home. Most of poisoning cases are unintentional and occurred at home due to ingestion of medicinal products. Therefore, awareness of parents about the potent poisons at home may help to minimize the occurrence of such adverse events.

Key word: Poisoning, Intentional poisoning, Unintentional poisoning, Drug overdose, Acute poisoning, Accidental poisoning, Poisoning mortality, Self-poisoning, Adverse drug reactions, Toxic agents, Child poisoning, Poison Control Center. 
medRxiv preprint doi: https://doi.org/10.1101/2020.04.27.20077420; this version posted May 5, 2020. The copyright holder for this preprint (which was not certified by peer review) is the author/funder, who has granted medRxiv a license to display the preprint in perpetuity. It is made available under a CC-BY-NC-ND 4.0 International license .

\section{Introduction}

Poisoning represents an injury caused due to exposure to an extrinsic compound which leads to cell injury and/or death. Exposure to poisons can be via absorption, ingestion, inhalation, or injection. The exposure can be acute or chronic, causing variable clinical presentations. Factors establishing the severity and outcomes of poisoning in an individual are interlinked and comprise dose, type of poison, formulation, route, presence of other toxins, and presence of other injuries $^{(1-2)}$. children are at greater risk of accidental poisoning ${ }^{(2)}$. The cases of accidental poisoning are quite common in the young ones due to innate enthusiasm to discover their surroundings with their taste ${ }^{(2)}$.

Poisoning incidents are a major health problem around the globe, the magnitude of which varies from one country to another. The data from the WHO reported that in 2002, roughly 350,000 people died due to accidental poisoning while in 2004, more than 45,000 deaths in individuals aged above 20 years died of acute cases of poisoning. It is also the $2^{\text {nd }}$ common reason for injury and hospitalization in children aged below 5 years ${ }^{(2)}$.

Cases of accidental poisoning occur frequently in the children below 5 years of age and $<1 \%$ of poisoning cases in children are serious ${ }^{(2)}$. The most regular causes of accidental poisoning involve over-the-counter/prescription drugs, general domestic products, kerosene, poisonous herbs, pesticides, sting/bites by insects etc. ${ }^{(1)}$. In order to prevent the poisoning cases in children, parents and care takers should be educated about the potential risk factors for poisoning and methods to reduce the incidence of poisoning in children ${ }^{(3)}$. The duration between toxic exposure and clinical manifestations poses a chance wherein, it is crucial to reduce the uptake by neutralizing and/or removing or via using various protective agents which thwart organ injury $(2,3)$.

In Saudi Arabia, a study to study the outcomes and management of cases of poisoning in young children admitted to hospitals in Saudi Arabia ${ }^{(4)}$, revealed that unintentional poisoning cases in children and adults were similar in different regions., and showed that there is a requirement of public understanding on how to storage the toxic materials and the need for an urgent hospitalization in case of accidental poisoning. The study recommended strategies on careful storage of drugs in order to decrease the associated adverse events ${ }^{(4)}$.

Another study in Saudi Arabia, reported that young children below 12 years of age were mostly affected by intoxications $(n=58,44.2 \%)$. Drug overdose $(n=119,92.2 \%)$ was found to be the frequent reason for poisoning and the nonsteroidal anti-inflammatory and analgesic agents were mostly involved $(n=26,20.4 \%)^{(5)}$. Example of studies that reported adverse events mainly poisoning, their type of intoxication and outcomes are reported in Table 1.

Most of the poisoning cases reported across the globe occur in children below the age of 5. Most of these affected children are boys ${ }^{(2,4,5)}$. The most prominent poisoning agent in high and middleincome countries is medicines as children accidentally consume medicines. Other poisoning agents are organic fuels, pesticides, household chemicals and carbon monoxide. In some of the Asian countries, (poisoning from bites and stings) from spiders, snakes and scorpions are also a common form of child poisoning. In Saudi Arabia, 30\% of poisoning in children of 6-12 years age is caused by envenomations. Management of poison cases in various countries depend on 
medRxiv preprint doi: https://doi.org/10.1101/2020.04.27.20077420; this version posted May 5, 2020. The copyright holder for this preprint (which was not certified by peer review) is the author/funder, who has granted medRxiv a license to display the preprint in perpetuity.

It is made available under a CC-BY-NC-ND 4.0 International license.

their socio-economic conditions as high income countries have good reporting and management facilities for the patients ${ }^{(6)}$.

The Saudi Arabia's Government has developed a mechanism for poison control, reporting and investigating the intoxications and drug abuse called the Poison Control and Forensic Chemistry Center, and available in eight centers across the Kingdom in every region ${ }^{(7,8,9)}$.

\section{Aims and Objectives}

The aim of this study was to assess the poisoning incidences that were reported centrally via the Saudi Arabian Ministry of Health Hotline Calling Center (937), and passed to Jeddah Poison Control and Forensic Chemistry for assessment and management. The objectives of this study were:

2? To identify the characteristics of poisoning in patients of different age and gender.

? To analyze the number of cases reported in various regions of the Kingdom.

? To explore the risk factors contributing to the reported poisoning incidences.

? To describe the management of cases reported to the poison control center. 
medRxiv preprint doi: https://doi.org/10.1101/2020.04.27.20077420; this version posted May 5, 2020. The copyright holder for this preprint (which was not certified by peer review) is the author/funder, who has granted medRxiv a license to display the preprint in perpetuity.

\section{Materials \& Methods}

This study was conducted from $1^{\text {st }}$ January 2020 to $30^{\text {th }}$ March 2020 . Data between 01-01-2019 to 30-12-2019 was collected from the Poison Control and Forensic Medical Center (PCFMC), Jeddah, Saudi Arabia. Information relevant to the "data collection form" was manually collected from archived files in the Poison Control Center. Data was collected with the help of clinical toxicologists. The clinical toxicologists in this poison center received calls from doctors in hospitals, medical centers and patients, to answer questions related to handling and treatment of poison cases. The patients included in this study were categorized on the basis of their gender and each gender was subcategorized on the basis of age. This study included cases of both acute and chronic toxicity. Factors responsible for toxicity including mode and time of poisoning were studied with respect to the variables.

The demographic variables included in this study were age, gender and region of poisoning. Various risk factors including type, pattern, place and route of poisoning were included. Various factors involved in management including any pre-hospital management, decontamination method and time of report were analyzed.

Multiple questions were included in the questionnaire to identify the identity of caller and the patient, personal history of the patient, reason for contacting the poison control center (complaint), poisoning data, general and systemic examination, routine and toxicological investigations, treatment provided, analytic report by medical toxicologist and prognosis of the condition.

Hand filled forms were collected from the PCFMC, Jeddah, Saudi Arabia. The forms were filled on the basis of calls received from different health sectors as well as public sectors via a specified phone number of the Ministry of Health by (937). This data was then typed in an Excel spreadsheet and checked for any incomplete or redundant information.

Statistical analysis of the data was done through IBM SPSS software, version $20^{(10)}$. 
medRxiv preprint doi: https://doi.org/10.1101/2020.04.27.20077420; this version posted May 5, 2020. The copyright holder for this preprint (which was not certified by peer review) is the author/funder, who has granted medRxiv a license to display the preprint in perpetuity. It is made available under a CC-BY-NC-ND 4.0 International license .

\section{Results}

Complete information, in the form of hand-filled forms, was obtained for 253 patients from PCFMC, Jeddah. All the data obtained from forms was carefully analyzed to compile the results.

\section{Patients Demography:}

Among the total 253 patients, 198 were up to 5 years of age while the rest of patients were more than 5 years old. Mean age of the patients, including both male and female, analyzed in this study was found to be $1.2( \pm 0.4)$ years. Incidence of poisoning was found in patients of both age groups i.e. 0-5 years and above 5 years of age. However, frequency of poisoning was much higher in children up to 5 years of age than the patients above 5 years of age as shown in Table 1.

Male and female patients were $(n=137,54 \%)$ and $(n=109,43 \%)$ respectively while gender of $3 \%$ patients could not be identified. Demographic variables of all the patients included in this study were successfully analyzed as shown in Table 2

\section{Geographical Locations of Adverse Events Report:}

Cases of poisoning were reported from various regions of the Kingdom. Incidences from the eastern, western, southern, northern and middle regions were found to be 14, 38, 20, 7 and $21 \%$ of the total cases, respectively.

\section{Poisoning Risk Factors:}

This study showed that poisoning cases included both chemical and drug poisoning. However, drugs $(n=155,61 \%$ cases $)$ were more significant risk factor than chemicals $(n=92,36 \%)$ as shown in Table 3.

For most of the cases $(n=233,92 \%)$, pattern of poisoning was accidental while only $(n=11,4 \%)$ of the cases were intentional (Table 3). Hospital or work place was not found to be the place of poisoning in most cases; most of the poisoning cases occurred at homes (96\%). About $94 \%$ of the poison entered the patients through oral route or ingestion $(n=242,94 \%)$ as shown in Table 3.

Intentional poisoning was more common in females $(n=8,3 \%)$, as shown in Table 3.

\section{Management Consultations by the Poison Center:}

All of the data in this study was received from professional doctors in the poison control center. About $12 \%$ of the poisoning cases were provided with some management at homes before coming to the hospital as shown in Table 4.

Once the poisoning patient reached the hospital, decontamination was performed with active charcoal ( $n=62,24 \%$ of the cases) or gastric lavage $(n=9,3.5 \%$ of the cases). About $(n=144$, $57 \%$ ) of the poisoning cases were reported within an hour while $43 \%$ were reported after an hour of poisoning as shown in Table 4. 


\section{Discussion}

Poisoning affects many people across the globe thereby causing injuries or even death. This study analyzed the details of patients who suffered from poisoning and reported to the Poison Control and Forensic Chemistry Center in Jeddah, Saudi Arabia. The results of the study showed that most of the poisoning cases occurred in male children under the age of 5 years. Most of the affected children were accidentally poisoned by ingesting drugs at their homes. The poisoning cases were mostly reported within an hour to the hospital without any pre-hospital management and treated with active charcoal.

The results of the currents study showed that $78 \%$ of the cases that were reported to the poison control center were children below the age of 5 years, similar to the findings of other studies that have shown the highest prevalence of poisoning cases were among pre-school kids, particularly around the age of 2 years ${ }^{(11)}$. Also, previous studies showed that that children of school age group from 6 to 12 years had the lowest exposure to poison ${ }^{(12)}$. These results are related with those of previous epidemiologic studies on pediatric poisoning which found a bimodal age distribution of poisoning with a high incidence among toddlers ${ }^{(13)}$.

In the current study, poisoning cases were found to be slightly more prevalent in males (54\%) than in females (43\%). These results relate with previous findings which showed that in the preschool and school age groups, boys exceeded in number as compared to the number of girls $^{(114151617)}$. Similarly, female cases were less common as compared to the males in the

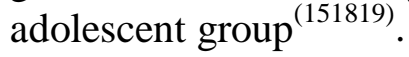

In this study, poisoning cases were reported from various regions of KSA. However, most of the cases were reported from Western and Southern regions while only a few cases were reported from the Northern region. This may be due to the reason that Northern region is less urbanized as compared to the Eastern and Western regions ${ }^{(20)}$ and parents are often not aware about how to report poison cases to the hospitals.

The current study also analyzed various poisoning risk factors, such that drug poisoning was more prevalent cause of poisoning than the chemical poisoning (Table 3). About $61 \%$ of the patients were poisoned with medicines, mainly due to accidental use of pharmaceutical agents without any prescription ${ }^{(13)}$. Since most of the patients in this study are below the age of 5 years, it is evident that they can mistakenly consume drugs accidentally as shown in this study. Kids below the age of 5 are generally unable to perceive what they should eat and what not. This is the reason for excessive poisoning due to medicine in children ${ }^{(21)}$.

It has been found that the most common pharmaceutical compounds linked to poisoning were non-opioid analgesics in studies based in Turkey ${ }^{(22)}$, Palestine ${ }^{(23)}$, Australia ${ }^{(24)}$, United Arab Emirates, Hong Kong, and Saudi Arabia ${ }^{(25)}$. On the other hand, it has also been reported that benzodiazepines, antimicrobials and opium were the most frequently involved drugs in France $^{(26)}$, Israel and $\operatorname{Iran}^{(27)}$, respectively. These variations might be brought up by the differences in the drug prescription patterns varying from country to country and country specific modifications to the packaging of the medicines and household chemicals. 
medRxiv preprint doi: https://doi.org/10.1101/2020.04.27.20077420; this version posted May 5, 2020. The copyright holder for this preprint (which was not certified by peer review) is the author/funder, who has granted medRxiv a license to display the preprint in perpetuity. It is made available under a CC-BY-NC-ND 4.0 International license .

Among pre-school and school age groups, the reason of the poisoning was predominantly the unintentional poisoning ${ }^{(111415161728)}$. However, in adults, higher rate of self-harm has been observed in adolescent females ${ }^{(29)}$ and it was explained by higher tendency of internalizing emotional and behavioral problems in female adolescents.

Place of poisoning was found to be home in $96 \%$ of the cases in this study. This is due to the reason that parents get unaware of their kids and the kids accidentally or unintentionally take a poison as reported previously ${ }^{(30)}$. Primary route of poisoning was found to be ingestion (94\%) in our study as compared to other routes $(6 \%)$ of poisoning like inflammation, dermal injury routes. This is in agreement with previous studies that have also shown active charcoal to be the primary method of poisoning decontamination ${ }^{(31)}$.

All of the data included in this study was provided by doctors or professionals that reduced the chances of any technical errors that could have been done by the non-professionals. As far as the management of poisoning cases is concerned, it was found that only $12 \%$ of the reported poisoning cases tried to do some kind of management at home while $87 \%$ were brought directly to the hospital. Most of the poisoning cases were managed in the hospital through decontamination with active charcoal $(24 \%)$ as shown in Table 3. Most of the cases (57\%) were reported within an hour. However, $43 \%$ of the cases were reported after one hour of poisoning. Previous studies have shown that active charcoal alone is better treatment for poisoning cases presented in hospital within one hour ${ }^{(32)}$. Since most of the patients were brought to hospital within 1 hour in our study, active charcoal management was the best option. This shows that the hospitals were adequately managing the poison cases.

Limitations of this study include small sample size and collection of data from only one poison control center. Greater sample size including data from extended time period, i.e., 1 year or more would have produced more detailed analysis. Despite these limitations, this study provided insight into the types and frequency of poisoning in a large city of Saudi Arabia, which merits a larger national investigation. 


\section{Conclusion and Recommendations}

The study revealed that poisoning was more prevalent in children below the age of 5, primarily males. High number of poisoning cases was reported in the Western and Southern regions while the lowest number of cases was found in the Northern region. It is concluded that most of poisoning cases were accidental and occurred at home due to ingestion of medicines. Intentional poisoning was more common in females. Most of the cases were reported within one hour of poisoning to hospital without any pre-hospital management. Prime method of decontamination at the hospitals was active charcoal.

It is recommended that parents should keep all medicines away from the reach of children, especially boys. People should be educated and special mechanisms should be developed in the Northern regions so that people can quickly report poisoning. Additionally, all the residents of the Kingdom should be educated to report the poisoning cases as soon as possible to the hospital so that chances of injury may be reduced ${ }^{(33)}$. 
medRxiv preprint doi: https://doi.org/10.1101/2020.04.27.20077420; this version posted May 5, 2020. The copyright holder for this preprint (which was not certified by peer review) is the author/funder, who has granted medRxiv a license to display the preprint in perpetuity. It is made available under a CC-BY-NC-ND 4.0 International license .

\section{References}

1. Lam, L. T. (2003). Childhood and adolescence poisoning in NSW, Australia: an analysis of age, sex, geographic, and poison types. Injury Prevention, 9(4), 338-342.

2. WHO-UNICEF. Children and poisoning: world report on child injury prevention. World Health Organization. 2008. [http://www.who.int/violence_injury_ prevention/child/injury/world_report/en/, date accessed: March 1, 2020.

3. Budnitz, D. S., \&Lovegrove, M. C. (2012). The last mile: taking the final steps in preventing pediatric pharmaceutical poisonings. The Journal of pediatrics, 160(2), 190192.

4. Alanazi, M.M.R., AlShammari, T.H., Alshehri, M.M., AlShammari, T.H., Alaradi, A.A., Alsagre, S.N., Alrumeh, H.S. and Alqahtani, M.S.A. (2018). Futures and the outcome of treatment of poisoned children and adolescents admitted to emergency units in different areas of Saudi Arabia. The Egyptian Journal of Hospital Medicine, 73(2), 5970-5975.

5. Bakhaidar, M., Jan, S., Farahat, F., Attar, A., Alsaywid, B., \& Abuznadah, W. (2015). Pattern of drug overdose and chemical poisoning among patients attending an emergency department, western Saudi Arabia. Journal of community health, 40(1), 57-61.

6. Peden, M., Oyegbite, K., Ozanne-Smith, J., Hyder, A. A., Branche, C., Rahman, A. K. M. F., .. \& Bartolomeos, K. (2009). World report on child injury prevention (Vol. 2008, pp. 1-28). Geneva: World Health Organization.

7. Alamri, S. A., Ali Al Jaizani, R., Naqvi, A. A., \& Ghamdi, M. S. A. (2017). Assessment of drug information service in public and private sector tertiary care hospitals in the eastern province of Saudi Arabia. Pharmacy, 5(3), 37.

8. Vassilev, Z. P., Chu, A. F., Ruck, B., Adams, E. H., \& Marcus, S. M. (2009). Evaluation of adverse drug reactions reported to a poison control center between 2000 and 2007. American journal of health-system pharmacy, 66(5), 481-487.

9. Al-Kandari, D., \& Jukes, D. J. (2012). The food control system in Saudi ArabiaCentralizing food control activities. Food control, 28(1), 33-46.

10. Heck, R. H., Thomas, S., \& Tabata, L. (2013). Multilevel modeling of categorical outcomes using IBM SPSS: Routledge Academic.

11. Azab, S. M., Hirshon, J. M., Hayes, B. D., El-Setouhy, M., Smith, G. S., Sakr, M. L., . . . Klein-Schwartz, W. (2016). Epidemiology of acute poisoning in children presenting to the poisoning treatment center at Ain Shams University in Cairo, Egypt, 2009-2013. Clinical toxicology, 54(1), 20-26.

12. Sahin, S., Carman, K. B., \& Dinleyici, E. C. (2011). Acute poisoning in children; data of a pediatric emergency unit. Iranian journal of pediatrics, 21(4), 479.

13. Kumar, J. S., \& Ravikanth Soni, D. K. A Prospective Study on Accidental Poisoning In Pediatric Patients.

14. Köse, S., Yorulmaz, H., Yorulmaz, E., \& Özdilli, K. (2010). Intoxication Cases Under Two Years of Age Monitored By Pediatric Emergency Room of Istanbul Şişli Etfal Education and Research Hospital. Journal of Academic Emergency Medicine/Akademik Acil Tip Olgu Sunumlari Dergisi, 9(2).

15. Laidlaw, M. A., \& Taylor, M. P. (2011). Potential for childhood lead poisoning in the inner cities of Australia due to exposure to lead in soil dust. Environmental Pollution, 159(1), 1-9. 
medRxiv preprint doi: https://doi.org/10.1101/2020.04.27.20077420; this version posted May 5, 2020. The copyright holder for this preprint (which was not certified by peer review) is the author/funder, who has granted medRxiv a license to display the preprint in perpetuity. It is made available under a CC-BY-NC-ND 4.0 International license .

16. Schmertmann, M., Williamson, A., Black, D., \& Wilson, L. (2013). Risk factors for unintentional poisoning in children aged 1-3 years in NSW Australia: a case-control study. BMC pediatrics, $13(1), 88$.

17. ve Araştırma, İ. Ş. E. E., İki, H. S. Ç. K. G., \& Olguları, Y. A. Z. Intoxication Cases Under Two Years of Age Monitored By Pediatric Emergency Room of İstanbul Şişli Etfal Education and Research Hospital.

18. Bari, M. S., Chakraborty, S. R., Alam, M. M. J., Qayyum, J. A., Hassan, N., \& Chowdhury, F. R. (2014). Four-year study on acute poisoning cases admitted to a tertiary hospital in Bangladesh: emerging trend of poisoning in commuters. Asia Pacific Journal of Medical Toxicology, 3(4), 152-156.

19. Jesslin, J., Adepu, R., \& Churi, S. (2010). Assessment of prevalence and mortality incidences due to poisoning in a South Indian tertiary care teaching hospital. Indian journal of pharmaceutical sciences, 72(5), 587.

20. Salam, A. A., Elsegaey, I., Khraif, R., \& Al-Mutairi, A. (2014). Population distribution and household conditions in Saudi Arabia: reflections from the 2010 Census. SpringerPlus, 3(1), 530.

21. Clippinger, A. J., Allen, D., Jarabek, A. M., Corvaro, M., Gaça, M., Gehen, S., . . . Hinderliter, P. (2018). Alternative approaches for acute inhalation toxicity testing to address global regulatory and non-regulatory data requirements: An international workshop report. Toxicology In Vitro, 48, 53-70.

22. DEMIRKAPU, M. J. Drug and addictive substance poisoning with medical pharmacologist assessment. Sabuncuoglu Serefeddin Health Sciences, 2(1), 40-54.

23. Organization, W. H. (1984). Report on intercountry meeting on essential drugs for primary health care, Amman, 26 September-2 October 1983.

24. Graham, G. G., Davies, M. J., Day, R. O., Mohamudally, A., \& Scott, K. F. (2013). The modern pharmacology of paracetamol: therapeutic actions, mechanism of action, metabolism, toxicity and recent pharmacological findings. Inflammopharmacology, 21(3), 201-232.

25. Gheshlaghi, F., Piri-Ardakani, M.-R., Yaraghi, M., Shafiei, F., \& Behjati, M. (2013). Acute poisoning in children; a population study in isfahan, iran, 2008-2010. Iranian journal of pediatrics, 23(2), 189.

26. Jones, J. D., Mogali, S., \& Comer, S. D. (2012). Polydrug abuse: a review of opioid and benzodiazepine combination use. Drug and alcohol dependence, 125(1-2), 8-18.

27. Haghighat, M., Moravej, H., \& Moatamedi, M. (2013). Epidemiology of pediatric acute poisoning in southern Iran: a hospital-based study. Bulletin of Emergency \& Trauma, l(1), 28.

28. Guntheti, B. K., \& Singh, U. P. (2016). A study of Unnatural Female Deaths reported to a tertiary care hospital in Khammam, Telangana. Journal of Indian Academy of Forensic Medicine, 38(4), 460-464.

29. Hawton, K., Bergen, H., Waters, K., Ness, J., Cooper, J., Steeg, S., \& Kapur, N. (2012). Epidemiology and nature of self-harm in children and adolescents: findings from the multicentre study of self-harm in England. European child \& adolescent psychiatry, 21(7), 369-377.

30. Kandeel, F., \& El-Farouny, R. (2017). Study of Acute Poisoning Cases in Children Admitted To Menoufia Poison Control Center (MPCC) During the Year (2016). Ain Shams Journal of Forensic Medicine and Clinical Toxicology, 29(2), 89-99. 
medRxiv preprint doi: https://doi.org/10.1101/2020.04.27.20077420; this version posted May 5, 2020. The copyright holder for this preprint (which was not certified by peer review) is the author/funder, who has granted medRxiv a license to display the preprint in perpetuity. It is made available under a CC-BY-NC-ND 4.0 International license .

31. Benson, B., Hoppu, K., Troutman, W., Bedry, R., Erdman, A., Höjer, J., . . . Caravati, E. (2013). Position paper update: gastric lavage for gastrointestinal decontamination. Clinical toxicology, 51(3), 140-146.

32. Christophersen, A. B., Levin, D., Høgberg, L. C. G., Angelo, H. R., \& Kampmann, J. P. (2002). Activated charcoal alone or after gastric lavage: a simulated large paracetamol intoxication. British journal of clinical pharmacology, 53(3), 312-317.

33. Assar, S., Hatami, S., Lak, E., Pipelzadeh, M., \& Joorabian, M. (2009). Acute poisoning in children. Pak J Med Sci, 25(1), 51-54.

34. Ford, M. D. (2010). Unintentional Poisoning in North Carolina. NC Med J, 71(6).

35. Brophy, T. J., Spiller, H. A., Casavant, M. J., Chounthirath, T., Smith, M. D., \& Xiang, H. (2014). Medication errors reported to US poison control centers, 2000-2012. Clinical toxicology, 52(8), 880-888.

36. Doğan, N. Ö., Savrun, A., Levent, S., Günaydın, G. P., Çelik, G. K., Akküçük, H., \& Çevik, Y. (2015). Can initial lactate levels predict the severity of unintentional carbon monoxide poisoning?. Human \& experimental toxicology, 34(3), 324-329.

37. Schwebel, D. C., Evans, W. D., Hoeffler, S. E., Marlenga, B. L., Nguyen, S. P., Jovanov, E., ... \& Sheares, B. J. (2017). Unintentional child poisoning risk: A review of causal factors and prevention studies. Children's health care, 46(2), 109-130.

38. González-Santiago, O., Morales-San Claudio, P. C., Cantu-Cardenas, L. G., \& FavelaHernandez, J. M. (2017). Unintentional and self-poisoning mortalities in Mexico, 20002012. PloS one, 12(7).

39. Sharif-Askari, F. S., Sharif-Askari, N. S., Javadi, M., \& Gholami, K. (2017). Adverse drug reactions reported to the drug and poison information center of Tehran, Iran. PloS one, 12(9).

40. Razwiedani, L. L., \&Rautenbach, P. G. D. (2017). Epidemiology of organophosphate poisoning in the Tshwane District of South Africa. Environmental health insights, 11, 1178630217694149.

41. Haghighat, M., Moravej, H., \& Moatamedi, M. (2013). Epidemiology of pediatric acute poisoning in southern Iran: a hospital-based study. Bulletin of Emergency \& Trauma, l(1), 28.

42. Jung, W. J., Yu, M. H., Lee, Y., Kim, H., Cha, Y. S., \& Park, K. H. (2018). Relative risk and clinical severity assessment in patients with non-oral route organophosphate poisoning compared with oral route poisoning. Yonsei medical journal, 59(8), 982-988.

43. Wang, L., Wu, Y., Yin, P., Cheng, P., Liu, Y., Schwebel, D.C., Qi, J., Ning, P., Liu, J., Cheng, X. and Zhou, M. (2018). Poisoning deaths in China, 2006-2016. Bulletin of the World Health Organization, 96(5), 314. 


\section{LIST OF TABLES:}

Table 1 Example of studies that reported adverse events mainly poisoning, their type of intoxication and outcomes.

\begin{tabular}{|c|c|c|c|c|c|c|c|}
\hline \# & $\begin{array}{c}\text { Population of the } \\
\text { study }\end{array}$ & $\begin{array}{l}\text { Country } \\
\text { of } \\
\text { publicatio } \\
\text { n }\end{array}$ & Type of poison & $\begin{array}{l}\text { Intent of } \\
\text { exposure }\end{array}$ & $\begin{array}{c}\text { Outcomes of } \\
\text { poisoning }\end{array}$ & $\begin{array}{c}\text { Why was this } \\
\text { study } \\
\text { included }\end{array}$ & References \\
\hline 1 & $\begin{array}{l}454,520 \text { humans came } \\
\text { to Poison Information } \\
\& \text { Education Centre }\end{array}$ & $\begin{array}{l}\text { New } \\
\text { Jersey, } \\
\text { USA }\end{array}$ & $\begin{array}{l}\text { Antidepressant } \\
\text { medication }\end{array}$ & Unintentional & $\begin{array}{l}\text { Adverse drug } \\
\text { reaction resulting in } \\
\text { hospitalization }\end{array}$ & $\begin{array}{c}\text { Drug } \\
\text { poisoning case }\end{array}$ & $\begin{array}{c}\text { Vassilev, Z. P., Chu, } \\
\text { A. F., Ruck, B., et } \\
\text { al., (2009)a }\end{array}$ \\
\hline 2 & $\begin{array}{c}8,500 \text { patients reported } \\
\text { to Poison Information } \\
\text { Center }\end{array}$ & $\begin{array}{l}\text { New } \\
\text { Jersey, } \\
\text { USA }\end{array}$ & $\begin{array}{l}\text { Cold \& cough } \\
\text { medication }\end{array}$ & Unintentional & $\begin{array}{l}\text { Adverse drug } \\
\text { reaction resulting in } \\
\text { hospitalization }\end{array}$ & $\begin{array}{c}\text { Drug } \\
\text { poisoning case }\end{array}$ & $\begin{array}{l}\text { Vassilev, Z. P., Chu, } \\
\text { A. F., Ruck, B., et } \\
\text { al., (2009)b }\end{array}$ \\
\hline 3 & 1,096 cases & $\begin{array}{l}\text { North } \\
\text { Carolina, } \\
\text { USA }\end{array}$ & Opioid analgesic & Unintentional & $\begin{array}{l}\text { Deaths due to } \\
\text { prescribed drugs }\end{array}$ & $\begin{array}{c}\text { Drug } \\
\text { poisoning } \\
\text { causing death }\end{array}$ & Ford, M. D. (2010) \\
\hline 4 & $\begin{array}{c}2,990,000 \text { unintended } \\
\text { patients came to Poison } \\
\text { Data Center }\end{array}$ & USA & Analgesic agents & Unintentional & $\begin{array}{l}\text { Moderate levels of } \\
\text { clinical effects }\end{array}$ & $\begin{array}{l}\text { Drug related } \\
\text { unintended } \\
\text { errors }\end{array}$ & $\begin{array}{c}\text { Brophy, T. J., } \\
\text { Spiller, H. A., } \\
\text { Casavant, M. J., et } \\
\text { al., (2010) }\end{array}$ \\
\hline
\end{tabular}




\begin{tabular}{|c|c|c|c|c|c|c|c|}
\hline 5 & $\begin{array}{l}74 \text { patients poisoned } \\
\text { due to insecure heating }\end{array}$ & USA & $\begin{array}{l}\text { Carbon monoxide } \\
\text { (CO) }\end{array}$ & Unintentional & $\begin{array}{l}\text { No deaths were } \\
\text { reported }\end{array}$ & $\begin{array}{l}\text { CO poisoning } \\
\text { reports at } \\
\text { hospital }\end{array}$ & $\begin{array}{l}\text { Doğan, N. Ö., } \\
\text { Savrun, A., Levent, } \\
\text { S., et al., (2015) }\end{array}$ \\
\hline 6 & $\begin{array}{l}87,375 \text { patients treated } \\
\text { for poisoning at } \\
\text { Poisoning Center }\end{array}$ & Egypt & $\begin{array}{l}\text { Non-opioid } \\
\text { analgesics, anti- } \\
\text { rheumatics \& } \\
\text { antipyretics }\end{array}$ & Unintentional & $\begin{array}{l}75 \% \text { had minor/no } \\
\text { effect, } 119 \text { deaths } \\
\text { due to pesticide } \\
\text { intake }\end{array}$ & $\begin{array}{l}\text { Drug related } \\
\text { poisoning }\end{array}$ & $\begin{array}{l}\text { Azab, S.M., Hirshon, } \\
\text { J.M., Hayes, B.D. } \\
\text { (2016) }\end{array}$ \\
\hline 7 & $\begin{array}{l}\text { Involuntary poisoning } \\
\text { in children reported at } \\
\text { Center of Injury } \\
\text { Prevention \& Control }\end{array}$ & USA & $\begin{array}{l}\text { Cosmetics \& } \\
\text { personal care } \\
\text { items, pain } \\
\text { relieving } \\
\text { medicine, } \\
\text { domestic cleaning } \\
\text { items }\end{array}$ & Unintentional & 35 deaths & $\begin{array}{l}\text { Poisoning } \\
\text { caused by } \\
\text { multiple } \\
\text { toxicants }\end{array}$ & $\begin{array}{c}\text { Schwebel, D. C., } \\
\text { Evans, W. D., } \\
\text { Hoeffler, S. E., et al., } \\
\text { (2017) }\end{array}$ \\
\hline 8 & $\begin{array}{l}\text { General population } \\
\text { including all age groups } \\
\text { and gender }\end{array}$ & Mexico & $\begin{array}{l}\text { Effluent gases, } \\
\text { alcohol \& } \\
\text { pesticides }\end{array}$ & Unintentional & $\begin{array}{l}21,700 \text { deaths, death } \\
\text { in most of the } \\
\text { reported cases }\end{array}$ & $\begin{array}{l}\text { Poisoning } \\
\text { related deaths }\end{array}$ & $\begin{array}{l}\text { González-Santiago, } \\
\text { O., Morales-San } \\
\text { Claudio, P. C., } \\
\text { Cantu-Cardenas, L. } \\
\text { G., et al., (2017) }\end{array}$ \\
\hline 9 & $\begin{array}{c}\sim 750 \text { patients at Drug } \& \\
\text { Poison Information } \\
\text { Facility }\end{array}$ & Iran & Antimicrobials & Unintentional & $\begin{array}{l}\text { Adverse drug effect } \\
(68 \%), \\
\text { hospitalization }(7 \%)\end{array}$ & $\begin{array}{l}\text { Drug related } \\
\text { poisoning }\end{array}$ & $\begin{array}{c}\text { Sharif-Askari, F. S., } \\
\text { Sharif-Askari, N. S., } \\
\text { Javadi, M., \& } \\
\text { Gholami, K. (2017) }\end{array}$ \\
\hline
\end{tabular}




\begin{tabular}{|c|c|c|c|c|c|c|c|}
\hline 10 & $\begin{array}{l}207 \text { cases within } 10 \\
\text { months }\end{array}$ & $\begin{array}{l}\text { South } \\
\text { Africa }\end{array}$ & $\begin{array}{l}\text { Organophosphate } \\
\text { poisoning }\end{array}$ & $\begin{array}{c}\text { Intentional } \\
(51 \%), \\
\text { Unintentional } \\
(22 \%)\end{array}$ & Few deaths $(3.4 \%)$ & $\begin{array}{l}\text { Organophosph } \\
\text { ate related } \\
\text { poisoning }\end{array}$ & $\begin{array}{c}\text { Razwiedani, L. L., \& } \\
\text { Rautenbach, P. G. D. } \\
\text { (2017) }\end{array}$ \\
\hline 11 & 273 patients & $\begin{array}{l}\text { Korean } \\
\text { Republic }\end{array}$ & $\begin{array}{l}\text { Organophosphate } \\
\text { poisoning }\end{array}$ & Unintentional & Hospitalization & $\begin{array}{l}\text { Organophosph } \\
\text { ate related } \\
\text { poisoning }\end{array}$ & $\begin{array}{c}\text { Jung, W. J., Yu, M. } \\
\text { H., Lee, Y., et al., } \\
\text { (2018) }\end{array}$ \\
\hline 12 & $\begin{array}{l}\text { Patients reported in } \\
\text { Chinese National } \\
\text { Disease Surveillance } \\
\text { Point systems }\end{array}$ & China & Pesticides & Unintentional & 4,936 deaths & $\begin{array}{c}\text { Pesticide } \\
\text { related toxicity } \\
\text { at National } \\
\text { level }\end{array}$ & $\begin{array}{l}\text { Wang, L., Wu, Y., } \\
\text { Yin, P., et al., (2018) }\end{array}$ \\
\hline
\end{tabular}


Table 2 Frequency and percentages of demographic variables

\begin{tabular}{llcc}
\hline Variables & & Frequency & Percentage (\%) \\
\hline Age & $0-5$ years & 198 & 78 \\
\hline \multirow{2}{*}{ Gender } & $>5$ years & 55 & 22 \\
& Male & 137 & 54 \\
& Female & 109 & 43 \\
& Unidentified & 7 & 3 \\
\hline Region of & Eastern region & 36 & 14 \\
poisoning & Western region & 97 & 38 \\
& Southern region & 50 & 20 \\
& Northern region & 18 & 7 \\
& Middle region & 52 & 21 \\
\cline { 2 - 3 }
\end{tabular}


Table 3 Frequency of poisoning risk factors

\begin{tabular}{llcc}
\hline Variables & Frequency & Percentage (\%) \\
\hline $\begin{array}{l}\text { Type of } \\
\text { poison }\end{array}$ & Chemical poisoning & 92 & 36 \\
& Drug poisoning & 155 & 61 \\
& Other & 6 & 3 \\
\hline $\begin{array}{l}\text { Pattern of } \\
\text { poisoning }\end{array}$ & Accidental & 233 & 92 \\
& Intentional & 11 (8 Female, 3 Male) & 4 \\
& Unidentified & 9 & 4 \\
\hline $\begin{array}{l}\text { Place of } \\
\text { poisoning }\end{array}$ & Hospital & 3 & 1 \\
& Home & 246 & 96 \\
\multirow{2}{*}{$\begin{array}{l}\text { Route of } \\
\text { poisoning }\end{array}$} & Ingestion & 1 & $<1$ \\
& Other & 242 & 64
\end{tabular}


Table 4 Management of poisoning cases at poison center

\begin{tabular}{llcc}
\hline Variables & & Frequency & Percentage (\%) \\
\hline Data provider & Doctor/Professional & 253 & 100 \\
& Non-professional & 0 & 0 \\
\hline Pre-hospital & Absent & 220 & 87 \\
& Present & 30 & 12 \\
\hline Decontamination & Gastric lavage & 9 & 3.5 \\
& Active charcoal & 62 & 24 \\
& Antidote & 4 & 1.5 \\
& No decontamination & 178 & 71 \\
\hline Time of & Now-1 hour & 144 & 57 \\
reporting & 1 hour and above & 109 & 43 \\
\cline { 2 - 3 } & & &
\end{tabular}

